Second Operation.-At 4:10 p. m., an operation was performed. The first wound in scalp and skull was opened and enlarged. The extradural abscess and mastoid antrum were healed and filled with healthy granulations. The dura bulged in opening over the temporosphenoidal Jobe. A crucial in(rision of the dura was made. The brain pulsated very little. A grooved director entered an abscess about one-half an inch beneath the surface of the brain. This abscess was one inch above and anterior to the extradural abscess. It contained two or three drams of pus. The wound was enlarged by sprealing closed artery forceps and soft rubber tube drainage was used, passing through a button-hole in the scalp.

Result.-Temperature records were 97.2 to 98.4 , pulse 64 to 70 after the second operation. Two days after the second operation the patient noticed that he could talk much better. His appetite soon returned, and was ravenous; his tongue (leared up. After four days the patient urinated voluntarily. He slept well, had no headache, and was bright, cheerful and happy. Five days after the operation photophobia disappeared. J)rainage was used three or four days only.

Subsequent History.-The patient left the hospital in three weks. He has been doing his work for several weeks. He writes letters correctly; occasionally he hesitates for a worl, but is considered entirely well. The time between first and second operations is quite a blank to him, though to his friends he appeared to be nearly himself.

The special features of this case are: First, the mild catarrhal otitis media, though early and efficiently drained, yet with severe sequele; second, abscess of distinctive localizing symptoms; and, third, the rapid and perfect recovery from word blindness and aphasia.

('orbett Building.

\section{OXYURIS VERMICULARIS FOUND IN THE VERMIFORM APPENDIX.}

\section{RALPH W. WAKEFIELD, M.D. BAR HARBOR, ME.}

Parasites found within the vermiform appendix have been so seldom reported that $I$ submit the following case, believing it to be of scientific interest.

Metchnikoff, Becouerel, Natale, Girard and others have reported finding lumbricoids; Bloodgood, round worms; and Rammstadt, the oxyuris.

The case was referred to me for operation by Dr. George R. Hagerthy.

Paticnt.-Female, white, single, 17 years old, housemaid by oecupation.

Family History-CUnimportant, except that father is syphiJitie.

l'crsonal History.-Patient had ordinary diseases of childhool. She enjoyed good health until one year ago, since which time she has suffered more or less from intestinal indigestion and constipation.

Present Trouble._Six weeks before operation patient was cired with colicky pain in right side of abdomen, radiating toward the back. There was nausea and vomiting; no per(n)tible rigidity of recti muscles; pulse and temperature normal.

Patient improved under treatment, but would relapse when olid food was taken. At time of operation patient's tempera ture and pulse were normal. There was intermittent pain and marked tenderness at McBurney's point; slight rigidity of right rectus muscle; no nausea or vomiting. Bowels were constipated.

Operation.-The appendix was removed without incident. No adhesions were found and the external appearance of the organ showed evidence of only a moderate inflammatory process.

The appendix was inflated with air and suspended in absolute alcohol for three days. On exposing the lumen by a longitudinal incision, a nest of some six or eight pin-worms was found imbedded in the wall of the organ at the extreme distal extremity. 'The parasites had penetrated about onethird the thickness of the wall and, no donbt, would have cansed a perforation had they been allowed to remain.

The patient made an uneventful recovery.

\section{A MODIFIED ESMARCH CHLOROFORM INITALER.}

W. H. ALLEN, M.D.

Anesthetist to the Eye and Ear IIospital. PITTSBCRG.

The inhaler illustrated herewith was designed primarily with the object in view of allowing the ancsthetist the practically free use of one hand for the control of the patient's jaw and the palpation of the facial artery. It also at all times prevents the chloroform from too elosely approaching the face, a point which I consider of paramount importance for the safety of the patient and one which is too often neglected. The percentage of chloroform and air may be varied by tho acljustment of the sliding arms ( $\left.\mathrm{A}, \mathrm{A}^{\prime}, \mathrm{A}^{\prime \prime}, \mathrm{A}^{\prime \prime \prime}\right)$, which have a range of extension from three-fourths of an inch to one and three-eighths inches, as well as by the rapidity with which the anesthetic is dropped. It will, however, rarely be found necessary to employ the inhaler at anything but its fullest extension.

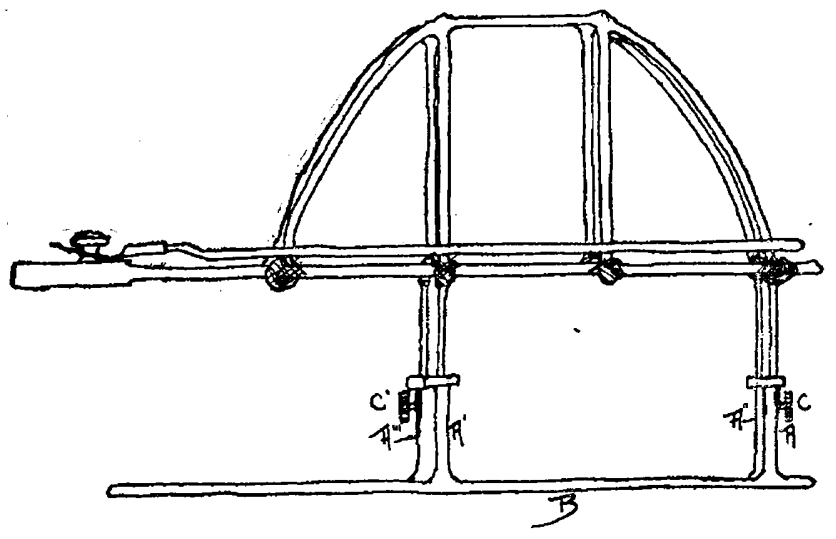

Fig. 1.-Modified inllaler. A, $\mathbf{A}^{\prime}, \mathrm{A}^{\prime \prime}$, $\mathrm{A}^{\prime \prime}$ uprights, having tele scopic adjustment; $B$, frame modeled to fit face; $C$, $C^{\prime}$, set-screws.

The construction consists of an ordinaly Esmarch inhaler from which, for convenience, the handle has been removed, with a wire frame (B), modeled to fit the face, attached below. This frame is connected with the inhaler by four uprights $\left(\mathrm{A}, \mathrm{A}^{\prime}, \mathrm{A}^{\prime \prime}, \mathrm{A}^{\prime \prime \prime}\right)$, having a telescopic aljustment controlled by two setserews (C, $\mathrm{C}^{\mathrm{I}}$ ). The part of the substage frame nearest the nose serves to hold a piece of gauze over the eyes of the patient.

The inhaler may readily be held in place by hooking the thumb of one hand aliont one of the uprights while the fingers control the jaw and palpate the facial pulse.

The whole inhaler may be readily cleaned and boiled. 2.52 Shady Avenue.

Contagion in Eczema.-M. H. Hallopeau, Bull. de la Soc. Francaise de Dermatologie, xix, January, 1908, avows himself an adherent of the parasitic theory of ee\%ema, and reports two cases in which the transmission of the disease from one patient to the other was, he thinks, hardly to be questioned. He does not consider the failure to detect the parasite as a valid argument against this theory; there are a number of transmissible diseases the microbe of which is unknown. The inflammation in eczema precedes the vesicle, and if a parasite is sought for it should be sought in the surrounding tissues rather than in the perfected vesicle 